\title{
Qur'anic Brevity and Verbosity: What and How?
}

\author{
Mazlan Ibrahim (Ph.D) \\ Associate Professor, Faculty of Islamic Studies, \\ The National University of Malaysia, 43600, Bangi, Selangor, Malaysia. \\ mazib@ukm.edu.my
}

\section{Abur Hamdi Usman}

Faculty of Islamic Studies, The National University of Malaysia, 43600, Bangi, Selangor, Malaysia. aburhamdiusman@yahoo.com

Mohd Akil Muhamed Ali

Faculty of Islamic Studies, The National University of Malaysia, 43600, Bangi, Selangor, Malaysia. aki@ukm.edu.my

\section{Doi:10.5901/mjss.2014.v5n20p1939}

\section{Abstract}

Arabic rhetoric is a linguistic means to a pragmatic end. Its major objective is to achieve succinctness and effective contextsensitive discourse. Hence, the stylistics (cilm al-Macani) is the second branch of Arabic rhetoric which deals with the semantic significance of words and expressions. It has to do principally with the art of conveying intended ideas or meaning successfully by skilful combination of words in a sentences or phrase. Thus, this study acquaints the usage of Qur'anic brevity and verbosity in the construction of verses. In this vein, however this study was selected one of the most recent exegetical work in the Archipelago as the object of study, namely al-Mishbah by Shihab. In interpreting the Qur'an, Shihab emphasizes the importance of Arabic to understanding the verses context and not focused on the text only. By doing so, to obtain a neat conclusion of this debate, this study uses literature and document analysis method with Tafsir al-Mishbah as a source of study inclusive of language and Tafsir books as major references. The findings showed that brevity identifies two kinds which are elliptical and succinctness. It is essential that omitted word(s) should not be a very essential part of the narration. The study also stipulates that verbosity may be used by way of emphasis or to obliterate ambiguity. In lieu of this, Shihab was applied brevity and verbosity method which is recognized and formulated by scholars and exegetes.

Keywords: Brevity, Verbosity, Shihab, Indonesia, Exegesis, Rhetoric.

\section{Introduction}

The spread of Islam all over the world also encourages the spread of the Arabic language; the language of the holy Quran and its prophetic texts. Thus, the Arabic language has been learnt and taught by different races and tribes from all over the world involving various teaching and learning methods (Mahmoud, 2013).

Arabic is spoken in large parts of the world extending from the Arabian Peninsula to the Atlantic Ocean. It has become an interest for millions of non-Arab Muslims, who do not speak it as a native language, to learn it at different levels, mainly because it is the language of the holy book, the Qur'an, and because of the fact that all Islamic terms are in Arabic (Nik Hanan et al., 2013).

Identifying an Arabic word (symbol) with a specific meaning is not usually an easy task. In linguistics, a word in isolation usually has no specific meaning unless it is used within a specific context. However, in lexical semantics, words are defined independent from their context. The purpose of lexicons and dictionaries is to identify all the meanings that a word means, regardless of its context. However, even when having a specific context, this does not imply that a word cannot have multiple meanings even within that context. These concepts of understanding the derivation of meaning from language and lexical semantics are extremely important when analyzing any literature, including the Qur'an (Abdulla, 2013). 
The Qur'an is the central religious text of Islam and, for Muslims, the book of divine guidance and direction. Its significance stems from the idea that it is the Word of Allah, revealed to the prophet Muhammad (PBUH) and therefore considered inimitable, as Allah states in sura Al-Isra (The Night Journey), verse 88 (Ameneh \& Hossein, 2013).

The scholars confirmed that the inimitability of the Qur'an and the inability of human beings to produce anything similar to it. Their opinions differed on the significance of inimitability of the Qur'an: (i) it is comprised of a strange organisational structure that is absolutely different from the organisation of the Arabs and their prose, in term of its phrases, idioms and rhymes. (ii) it is free from incompatibility, inconsistency and mutual contradiction. (iii) included in the Qur'an are the excellent and meritorious phenomenon, amazing and marvellous things at the openings, and at the end of each chapter. (iv) purity and eloquence of the language. (v). rhetoric in the meanings of figurative or allegorical expressions. (vi) illustration of the organized science of metaphors (al-Qattan, 1992). All these aspects do not step out of the boundary of the rhetorical circle, which is a factor that makes the Text inimitable and miraculous (Ushama, 2002).

Rhetoric is a linguistic discipline that aims to sharpen up and upgrade the linguistic competence of writing and speaking. It provides us, as language users, with the appropriate and effective stylistic mechanisms required for eloquently forceful discourse. Thus, Arabic rhetoric makes language meet the communicative needs of the language user. It is concerned with speech acts which are pregnant with communicative goals. Therefore, it plays a significant role in interpersonal communication (Raof, 2006). Rhetoric is the compatibility of an eloquent discourse to context and is attributed to cognition and to elegant discourse (al-Jarim \& Amin, 1998). Rhetoric as help in understanding of the meaning and deepen sign language style of the Qur'an. With this knowledge skill, the uniqueness of the Qur'anic language will be highlighted and the implied meaning will be clarified. In turn, will help a person to understand Qur'anic text in depth and full appreciation (Roslan, 2013). Therefore, it is the highest level of discourse when the lexical items are selected and ordered accurately in a given proposition.

Basicly, this humble study focuses on the discourse of interpretation's rules used by Shihab ${ }^{1}$ in his Tafsir $^{2}$ its related with Arabic rhetoric. As known the study of Arabic rhetoric requires an in-depth investigation of its three major constituent disiplines: stylistics (cilm al-Macani), figures of speech (cilm al-Badic) and embellishments (cilm al-Bayan). For a neater explanation, the present study provides a bird's-eye about brevity and verbosity which particularly concentrating in cilm al-Macani. In this case, will be elaborated on the terminology aspects, then analyze the validity of the interpretation's rules related with both terms in Tafsir Al-Mishbah.

The concern of this study, however, is not brevity in general; nor is it simply Shihab's understanding of brevity, but of Shihab's application of Qur'anic brevity, specifically. Thus, the research methodology used is literature review with analytical approach, that is, analysis of Shihab's exegesis, especially in the aspect of linguistic, and followed by review and comments. Data collection is the most common method to obtain data or facts related to the subject of research. The first source is Tafsir Al-Mishbah written by Shihab himself. The second source is the books, journals, written papers and other suitable materials. All of these materials will be discussed in this article by adopt library research.

\section{The Notion of Brevity And Verbosity: Linguistic Basis}

c/lm al-Macani (the science of stylistics) is a grammar-governed sentence-level approach that is concerned with the pragmatic and aesthetic effects of the judicious ordering of lexical items within a given proposition (Husain, 1977). It was defined as consisting in the study of the properties of the structure of utterances in speech and the evaluation thereof, in

\footnotetext{
1 Shihab was born in Rappang, South Sulawesi on $16^{\text {th }}$ February 1944. His early education was obtained from his father, Abdulrahman Shihab. His love towards the Qur'an blossomed from the age of six (Shihab, 1992). As a son of a famous exegete, he was often brought by his mother to attend religious classes delivered by his father. His mother also became the fuel in shaping his interest. Her constant encourgements and guidance resulted to the choice of majoring in the same field for his further study. Other than his parents early involvements at home, he also studied at Pondok Pesantren Darul Hadith al-Faqihiyyah, Malang. Soon after, in 1958 the state of Sulawesi awarded him a scholarship to study at the University of al-Azhar, Cairo, Egypt, and accepted to grade two thanawiyyah alAzhar. His academic journey later took him to the Department of Theology, University of al-Azhar majoring in Tafsir and Hadith. He completed his bachelor degree in 1967. Two years later (1969), he managed to obtain a master degree in the same field In 1980, Shihab furthered his Ph.D degree in the same university. He completed his study in two years and obtained grade mumtaz maca martabah alsharaf al-ula (exemplary scholar with outstanding performance). His outstanding results qualified him as the first South East Asian student successful in obtaining a Ph.D degree in the Qur'anic sciences from al-Azhar University (Shihab, 2011). The process of intellectual growth experienced by Shihab for 13 years at the University of al-Azhar shaped his form of thought.

2 Tafsir Al-Mishbah is a complete exegetical work consists of 30 parts in 15 volumes. It is written when Shihab was Ambassador of Indonesian Republic in Egypt and its completed after four years. It started in Cairo on Friday 18 June 1999 and finished in Jakarta on Friday, 5 September 2003 after spending approximately seven hours per day (Mazlan \& Abur, 2013a.).
} 
order to avoid mistakes in the use of language in accordance with the requirements of the situation. In the field so defined would be treated all the questions relating to grammatical semantics and pragmatics (al-Hashimi, 1960). In other words, it is concerned with language and context, i.e. the pragmatic effects of such word orders in Arabic. Thus, word order is related to the deliberate and skilful manipulation of language by the text producer.

Abu Zahrah (1970) classifies the lexical items from brief or breadth into four types, namely al-ijaz (brevity), al-taqsir (abridgment): does not enough to express the intended meaning, al-itnab (verbosity), and al-tatwil (prolixity): when a pronouncement exceed the meaning without benefit. However, he states that abridgment and prolixity can not be classified as Qur'anic rhetoric.

In scholastic rhetoric, brevity is regularly discussed in the section on al-Macani, together with its opposite verbosity. Brevity was highly esteemed as a stylistic virtue in traditional Arabic criticism, in prose as well as poetry, although it was recognized that some circumstances called rather or prolixity. Lip-service to the ideal is often paid in the prefaces of prose works. The term brevity may be used in a loose sense for texts as a whole. When applied to the level of sentence, a distincion is made between brevity as the result of elision (Van Gelder, 2010).

Pre-Islamic Arabs considered brevity a beauty of speech because, to them, hints sufficed for the intelligent (alFarahi, 1991). Brief statements were viewed by the Qur'anic era Arabs as indicative of eloquence-related abilities of the speaker (al-Zarkashi, 1988). Since the Qur'an had to penetrate the minds and hearts of linguistically-sensitive people, it used brevity as a main feature of its speeches. Had it ignored the Arab's standard of oration, it would most certainly have been rejected. There is no denying the fact that Islamic revolution in the Arabian Peninsula was, among other things, consequent upon the most effective and cohesive language of the Qur'an, which was actually the result of its brevity (Khan, 2006).

Brevity means a statement where a word is used in a particularly limited sense comprises restrictive brevity (alSuyuti, 2000). It is concerned with effective communication and the production of a given proposition with minimal lexical items. However, brevity in discorse should not lead to ambiguity and the adressee should have access to contextual cliues that enable him or her to infer the implacature of a given proposistion. The main pragmatic reasons for brevity are to avoiding boredom to the addressee, ease of processing the information by the addressee, and limitation of time and space on the part of communicator (Raof, 2006).

Brevity is a stylistic device in which only the kernal of an idea is presented, and all subsidiary details are omitted. Brevity has wealth of meaning (Ahmed, 2004). Rhetorecally, brevity is to bring together many meanings under a few words while at the same time being clear and eloquent.

Verbosity is a rhetorical technique that aims to provide informativity to the addressee using more lexical items than is actual required ( $\left.{ }^{\circ} \mathrm{Abbas}, 2000\right)$. The pragmatic functions of verbosity are: (a). To influence the addressee and raise his or her sympathy and affection, (b). To achieve affirmation, (c). To express respect to the addressee, (d). To avoid ambiguity, and (e). To provide clarification (Raof, 2006).

\section{The Qur'anic Brevity And Verbosity: Its Application In Tafsir Al-Mishbah}

Shihab is very concerned about the importance of language in exegeting the Qur'an. He states that in order to understand the Qur'anic content, in-depth knowledge of the Arabic language used in the Holy book is pivotal. It can help one understand the meaning of each word in a verse, where one shall first review the meaning in the word and then set the most appropriate meaning after analyzing all aspects relating to the verse (Mazlan \& Abur, 2013b.). This approach is used consistently in each verse he analyzed. He was very attentive to the vocabulary meaning or the Qur'anic expressions with reference to the opinions of the language experts. In addition, he always questioned how the vocabulary is used in the Qur'an (Mazlan \& Abur, 2013c.).

An effective communicator aims to achieve effective discourse that expresses his or her feelings, ideological states, and points of view through one the brevity and verbosity. However, discourse, cannot be effective if it is incompatible with the psychological or ideological state of the addressee and the context of situation. Having this in mind, an effective communicator is aware of the context that requires brevity and the context which necessitates verbosity.

The Qur'an conformed to Arab speech: it provided the reason for codifying Arabic grammar and stylistics and was used as a criterion for these disciplines. Hence, to identify several verses of the Qur'an that uses brevity and verbosity, this study aims to analyze one of the most popular tafsir in the archipelago, namely Tafsir Al-Mishbah. This book has been selected due to his exegete strongly emphasizes an understanding of the Qur'anic meaning based on vocabularical analysis. In other words, Shihab adopts a linguistic approach in his exegetical work. One of the most interesting approach is based on brevity and verbosity that can be described in detail as follows: 


\subsection{The brevity, it comes in two categories:}

a. Elliptical (ljaz al-hadf), is a brief expression but contains wide meaning by removing some words either in part or in a complete sentence. However, the expression must be include the meanings of words that have been removed ( ${ }^{\mathrm{c}} \mathrm{Abbas}$, 2000). Hence, when a word, sentence or more is omitted or dropped while at the same there is a qarinah (textual indicator) which specifies that which has been omitted or dropped. Rhetorically, it can be understood even though the absence of the words removed without spoiling the comprehension. below:

Shihab (2010) applies this method while commenting on sura al-Waqicah (The Inevitable, 56) verse 70 as stated

"If We willed, We could make it bitter, so why are you not grateful?"

Shihab (2010, v. 3, p. 374) states that the above verse does not use the letters of lam that serves as reinforcement when explaining the power of God to make the rainwater becomes salty. This verse just mentioned jacalna, and aims to summarize when verse 65 has used it. This regard is different while describing His power to destroy the plant as specified in verse 65 with lajacalnahu, or because human involvement in farming seen clearly, so there is no wrong if one assumes that humans have the power in their growth. Therefore, this verse should be an emphasis on the power of God which is marked with the letter of lam. It is different with the rain, since there is no human involvement.

Based on this exegesis, it can be understood that when explaining the power of God makes the rainwater to be salty, the verse 70 has been removing the letter of lam (which serves as a reinforcement) on jacalna utterance. This is distinct in verse 65 previously that uses the letter when describing His power to destroy the plant, until expressed with lajacalnahu. Removing the lam on jacalna intended to summarize, because verse 65 has used it ('Ashur, 1984). In addition, verse 70 of sura al-Waqciah above does not require the use of lam to prove the power of God to make rain ater, since no human involvement in the process of creation. In other words, it can be understood despite the absence of a removed letter without spoiling an understanding. This is in contrast to verse 65 , as human involvement in the farm seen clearly, and perhaps some people who consider that they have the power to regenerate the crops. Therefore, here it should be emphasized on the power of God that is marked with the letter lam.

Accordingly, the exegetes also expressed the argument as presented by Shihab. Al-Zamkhshari (2000) for example, he stated that the letter lam in verse 70 is not used due it is known for certain that the rainwater becomes salty is God's power. This means no need to repeat something that has been known by the addresser. Thus, Abu Sacud (1994) explains the secret behind this phenomenon that the letter lam in verse 70 is not used as a guide for mankind on the differences between meals and beverages in terms of importance, as well as the difficulties in making both. With that, it would be seen clearly the power of God to make people more grateful. Al-Qasimi (1998) was think so. He specifies that according to habits and norms, changing water into salt is easier than making foodstuffs, so in verse 70 does not need to use the lam as strengthening element. This is different in verse 65 that uses it to prove concretely that the food is made by God.

Another example of elliptical brevity is Shihab's exegesis in sura al-Tahrim (The Prohibition, 66) verse 5 below:

"Perhaps his Lord, if he divorced you [all], would substitute for him wives better than you - submitting [to Allah ], believing, devoutly obedient, repentant, worshipping, and travelling - [ones] previously married and virgins".

Shihab $(2010, v .14$, p. 174) states that the admirable attributes mentioned in the above verse without using a conjunctions of waw, except the phrase of wa thayyibatin abkaran 'previously married and virgins'. It shows that every attribute referred very stable and decorate all the wives that he would marry (if present wives still painful to the Prophet). If the attributes specified by using conjunctions of waw, there are those who may consider that some of them just adopt $A$ and B's attributes only, while others simply the B and C's only, and so on.

Based on Shihab's exegesis it can be understood that the admirable attributes stated in the above verse do not use a conjunctions of waw, the purpose is conveyed by all the attributes mentioned are very stable and owned by each prospective wives of the Prophet. An elimination of waw in this verse is meant by elliptical brevity. Hence, ${ }^{c}$ Ashur (1984) states that if the attributes specified by using a conjunction of waw, then it will be understood that some of them are practicing one of the attributes and others were not. Unfortunately, this meaning is not intended by the verse. Yet, in the next phrase wa thayyibatin abkaran the waw is required, due the thayyibatin asserted is not necessarily practiced by abkara and vice versa. In other words, some of them have a thayyibatin and some abkara (al-Qurtubi, 1964).

b. Succinctness (ljaz al-qasr), is when short expressions are made to incorporate numerous meanings without any 
omitting any words (al-Qazuwayni, 1998). In other words, this is a succint mode of discourse that does not involve ellipsis. Qur'anic discourse is marked by this rhetorical feature, as in Shihab's exegesis in sura al-Waqciah verses 20 and 21 below:

"And fruit of what they select, And the meat of fowl, from whatever they desire".

Shihab (2010, v. 13, p. 348) states that this verse mentions one type of food only, and not to say other than it was not served. The mention of one type here is assessed the most luxurious and delicious in general, so if such has been served, then the others do, too.

Based on Shihab's exegesis it can be understood that the above verse has encompassed a variety of foods, although one type mentioned. One type of fruit or meat in this verse because it is the most perfect type of food (al-Sacdi, 2000), thus it has represent a variety of other foods. If such a nature has been served, of course, other dishes is so.

Another example of succinctness brevity is presented when Shihab interpretes sura al-Hadid (The Iron, 57) verse 12 as follows:

"On the Day you see the believing men and believing women, their light proceeding before them and on their right, [it will be said], "Your good tidings today are [of] gardens beneath which rivers flow, wherein you will abide eternally." That is what is the great attainment".

Shihab $\left(2010, v .13\right.$, p. 423) states that the phrase yas ${ }^{c} a$ nuruhum bayna aydihim wa biaymanihim 'their light proceeding before them and on their right', shows that two directions only mentioned. However, it does not mean that the two intended directions only, but the whole directions. The mention of both in this verse because it is the most precious indicating that they accept their scriptures from the right. This fact is in contrast to the dwellers of hellfire who receive it from the left.

Based on Shihab's exegesis it can be understood that needless to be stated specifically each direction in the above verse, such as left, right, front, back and forth. However it is sufficient to mention two directions, ie, forward and right to show the condition of believers should receive the record of their deeds from both. By doing so, this verse provides an understanding of opposite meaning that the unlucky people who will accept his record from the left and back (al-Zamakhshari, 2000). ${ }^{3}$

\subsection{The Verbosity}

One of the privileges Arabic is its tendency to verbosity, but it is done when absolutely necessary. It is intended to clarify the messages by the addresser. Furthermore according to Shihab (2013) situation and condition have a very significant influence in selecting the word and modify it to be a single correct sentence, meaningful and effective in addressee's heart. Addresser demanded to know how the addressee's attitude, does he believe, doubt or reject the news will be presented to him. Shortly after, the addresser able to modified the right sentences according to an addressee attitude.

A clear example of this method is when Shihab (2010) interprets sura al-Sajdah (The Prostration, 32) verse 22 as follows:

"And who is more unjust than one who is reminded of the verses of his Lord; then he turns away from them? Indeed We, from the criminals, will take retribution."

Shihab (2010, v. 10, p. 391) notes that the word al-mujrimin 'criminals' mentioned here even change it to 'them' simpler and gives the same meaning is intended to mention their disobedience and its very rigid and embracing all criminals to the God's decision. From another angle, the words mentioned before an utterance of muntaqimun 'We shall exact due retribution' aims to emphasize the punishment falls on them specifically.

Based on Shihab's exegesis above it can be understood that the utterance of al-mujrimin exceed the required meaning. Hence the pronoun of minhum as reference to the criminals is evaluated more brief and contains the same meaning of al-mujrimin. However, the al-mujrimin is used in this verse to achieve affirmation, that their disobedience and its highly hardcore (al-Alusi, 1995) and include all transgress to Allah's command. Thus, Ibn al-Juzzi stated that this verse was originally said inna minhu muntaqimun, but its added with al-mujrimin here to replace the pronoun position, and to inform their nature of crimes beyond the confines. In this case, the al-mujrimin utterance is specifically named verbosity.

${ }^{3}$ Also see Shihab's exegesis using this method in sura al-Hadid 57: 4 and al-Mujadalah 58: 7. 
Accordingly, this study also found a similar interpretation proposed by al-Zamakhshari (2000) and Ibn cAjibah (2002) in their books.

Another example of verbosity is presented when Shihab (2010) interpretes sura al-Hashr (The Exile, 59) verse 22 as follows:

"He is Allah, other than whom there is no deity, Knower of the unseen and the witnessed. He is the Entirely Merciful, the Especially Merciful".

Shihab (2010, v. 13, p. 559) stated that utterance of Allah when viewed at a glance is not needed, because the pronoun of huwa has referred to Him. However, this verse is described all His attributes before mentioning the special attributes. Thus, the utterance of Allah is a reference to His entity and necessary existence with all His attributes, whether Allah's essence or His actions. When you say "Allah", you mean it encompasses all His Names, but if specifically mention his name, such as al-Rahim 'the Most Merciful' or al-Malik 'the Sovereign', then both just show His compassion and ownership only.

Based on Shihab's exegegesis above it can be understood that the utterance Allah is needed to have a very important function, which is to emphasize the point that His Glorious name contains the whole of His attributes ('Ashur, 1984). By doing so, this verse provides a broader comprehension that His attributes such as al-Rahman 'the Most Compassionate' and al-Rahim have been covered by the utterance of Allah.

Another example of verbosity is shown when Shihab (2010) interpretes sura al-Mumtahanah (She that is to be Examined, 60) verse 6 as in:

"There has certainly been for you in them an excellent pattern for anyone whose hope is in Allah and the Last Day. And whoever turns away - then indeed, Allah is the Free of need, the Praiseworthy".

Shihab $(2010, v .13$, p. 594) stated that the articulation of the phrase liman kana wal yarjullaha yawmal akhir 'for anyone whose hope is in Allah and the Last Day' despite the pronoun of lakum which previously mentioned is sufficient to understand the meaning, which is to explain that the people who expect rewards from Allah and happiness in hereafter definitely concerned on Allah's demands, whereas to be negligent they are not considered to expect the rewards.

Based on Shihab's exegesis it can be understood that this verse requires the articulation of the phrase liman kana wal yarjullaha yawmal akhir, it has close ties with the meaning conveyed by the next phrase, which waman yatawalla fainnallaha al-ghaniy al-al-Hamid 'and whoever turns away - then indeed, Allah is the Free of need, the Praiseworthy'. In this case, the meaning to be conveyed is not duly the believers to decide liaison with Abraham AS and his followers, it shows wrong faith. Thus, this verse affirms who turns away to follow them, then the consequences will befall himself (alQasimi, 1994). In other words, the articulation of lakum only without the phrase liman kana wal yarjullaha yawmal akhir is not adequate, as it will cause the phrase Waman yatawalla fainnallaha al-ghaniy al-hamid cannot be properly understandable. ${ }^{4}$

\section{Conclusion}

The literary exegesis examines the Qur'an with regard to linguistic and literay aspects relating to syntax, morphology and rhetoric. Many scholars working in the domain of Qur'anic sciences have maintained that a Qur'anic exegete must be fully acquinted with Arabic lexicology, syntax, morphology, philology and rethoric. The Qur'an has used brevity and verbosity as one of its stylistic features. The language of the Qur'an does not contain any redundancy. The Qur'an abounds in aphorisms which are the best examples of this style.

Brevity connotes the usage of conciseness in the construction of sentences to convey one's ideas. This is achieved by means of using very few words to convey very long ideas. It is also where a part of the narration can be deliberately omitted. Verbosity on the other hands implies elaboration where the wording exceeds the meaning for useful purpose. However, too many details make the text non-effective and make it marked by bombast and prolixity in which case the text becomes boring due to the stylistic fact that is unnecessarily protracted.

Shihab is one of the archipelago scholar who stress the importance of understanding the verses meaning based on language analysis then the true meaning was required by the verse can be highlighted. Of that interests, Shihab was applied the brevity and verbosity method in his book, Tafsir Al-Misbah. Accordingly, this study found his exegesis has used this method which is recognized and formulated by scholars and exegetes.

${ }^{4}$ Also see Shihab's exegesis using this method in suras Ali clmran 3: 42 \& 126 and al-Munafiqun 63: 1. 


\section{References}

cAbbas, F. H. (2000). al-Balaghah: Fununiha wa Afnaniha, vol. 1. Oman: Dar al-Furqan.

Abdulla. G. (2013). The role of intertextual polysemi in Qur'anic exegesis. International Journal of Quranic Research (IJQR). Vol.3, no. 4, June: 36.

Abu al-Sacud. (1994). Irshad al-cAql al-Salim ila Mazaya al-Ktab al-Karim, vol. 8. Beirut: Dar Ihya' al-Turath al-cArabi.

Abu Zahrah. (1970). Al-Mucjizah al-Kubra al-Quran. Beirut: Dar al-Fikr al-Arabi.

Ahmed, H. (2004), A New Approach to The Study of The Qur'an. India: Goodword.

al-Alusi, S. M. (1995) Ruh al-macani fi Tafsir al-Quran al-cAzim wa Sabcu al-Mathani, vol. 21. Beirut: Dar Ihya' al-Turath al-cArabi.

Ameneh, M. \& Hossein, P. (2013). The trace of translators' ideology: A case study of English translations of the Qur'an. 3L: The Southeast Asian Journal of English Language Studies. Vol 19 (1): 51-64.

cAshur, M. T. (1984) al-Tahrir wa al-tanwir, vols. 27 \& 28. Tunisia: Dar Sahnun.

Al-Farahi, A. H. (1991), Rasail: Dalail al-Nizam, Asalib al-Qur'an, al-Takmil fi Usul al-Ta'wil. India: al-Dairah al-Hamidiyah.

al-Hashimi, A. (1960), Jawahir al-Balaghah fi al-Macani wa al-Bayan wa al-Badic. Egypt: Maktabah al-Tijariah al-Kubra.

Husain, cA. Q. (1977), Fan al-Balaghah. Cairo: Muassasah al-Risalah.

Ibn cAjibah, A. A. (2002), al-Bahr al-Madid fi Tafsir al-Quran al-Majid, vol. 4. Beirut: Dar al-Kutub al-cllmiyyah.

al-Jarim, cA. \& Amin, M. (1998), al-Balaghah al-Wadihah. Egypt: Dar al-Macarif.

Khan, I. A. (2006), Understanding The Qur'an: A Reflection. Kuala Lumpur: IIUM Malaysia.

Mahmoud, A. R. et al. (2013), Integration of an Interactive Program in Learning Arabic Language for Non-Native Speakers via Virtual Tutor. GEMA Online ${ }^{\mathrm{TM}}$ Journal of Language Studies, vol. 13 (3), September 2013, p. 118

Mazlan, I. \& Abur, H. U. (2013a.) Rules of M. Quraish Shihab Exegesis in Tafsir Al-Mishbah. World Journal of Islamic History and Civilization, 3 (3): 101-108. DOI: 10.5829/idosi.wjihc.2013.3.3.3303.

Mazlan, I. \& Abur, H. U. (2013b.) The Rule of Interpretation: A Comparative Study Between M. Quraish Shihab With al-Tabari. Advances in Natural and Applied Sciences, 7 (1): 15-22.

Mazlan, I. \& Abur, H. U. (2013c.) M. Quraish Shihab's Thought about Adulterer and Thief In Tafsir Al-Mishbah: A Critical Analysis. Australian Journal of Basic and Applied Sciences, 7 (4): 63-67.

Nik Hanan, et al. (2013). Arabic Language Efficacy Questionnaire (ALEQ): Assessing Self-Efficacy and Achievement. GEMA Online ${ }^{\text {TM }}$ Journal of Language Studies, 155, vol. 13 (1), February: p. 157.

Al-Qattan, M. (1992) Mabahith fi cUlum al-Quran. Beirut: Mu'assasah al-Risalah.

Al-Qasimi, M. J. (1994). Mahasin al-ta'wil, vol. 9. Beirut: Dar Ihya' al-Turath al-cArabi.

Al-Qazuwayni, K. (1998). Al-Idah fi cUlum al-Balaghah. Beirut: Dar Ihya' al-cUlum.

Al-Qurtubi, A. A. (1964), al-Jamic li Ahkam al-Quran, vol. 18. Cairo: Dar al-Kutub al-Misriyyah.

Raof, H. A. (2006), Arabic Rhetoric: A Pragmatic Analysis. New York: Routledge.

Roslan, A. R. (2013), Research on the Writing History of Arabic Rhetoric Studies and its Importance. Academic Journal of Interdisciplinary Studies, vol. 2, no. 9, October, p. 524.

al-Sacdi, A. N. (2000), Taysir al-Karim al-Rahman min Tafsir al-Kalam al-Mannan. Beirut: Mu'assasah al-Risalah.

Shihab, M. Q. (2013), Kaidah Tafsir: Syarat, Ketentuan, dan Aturan yang Patut Anda Ketahui dalam Memahami Ayat-Ayat al-Qur'an. Jakarta: Lentera Hati.

Shihab, M. Q. (2011), Membumikan Al-Qur'an jilid 2: Memfungsikan Wahyu Dalam Kehidupan. Jakarta: Lentera Hati.

Shihab, M. Q. (2010), Tafsir Al-Mishbah: Pesan, kesan dan keserasian Al-Qur'an, vols. 10, 13 \& 14. Jakarta: Lentera Hati.

Al-Suyuti, J. (2000). Al-Itqan fi cUlum al-Quran, vol. 2. Beirut: Dar al-Kutub al-cllmiyyah.

Ushama, T. (2002), Issues in the Study of The Qur'an. Kuala Lumpur: IImiah Publishers.

Van Gelder, G. J. H. (2010). ljaz, in The Routledge Encyclopedia of Arabic Literature, Julie Scott Meisami \& Paul Starkley (Eds.). New York: Routledge, p. 390.

Al-Zamakhshari, A. Q. (2000). Al-Kashshaf, vols. 3 \& 4. Cairo: Maktabah al-Misr.

Al-Zarkashi, B. M. (1988), al-Burhan fi cUlum al-Quran, vols. 1 \& 3. Cairo: Dar al-Turath. 